УАК 616.314.17-008.1.001.6:611-018

(C). А. Гасюк, А. М. Король, А. В. Калашніков

АВНЗ «Тернопільський державний медичний університет імені І. Я. Горбачевського» ВАНЗ України «Українська медична стоматологічна академія», м. Полтава

\title{
Гістотопографічні особливості періодонтальної щілини зуба в експерименті
}

Резюме. Автори провели гістотопографічні дослілження періодонтальної щілини зубів у собак і дійшли висновку, що маргінальний відліл зв' язкового апарату складається переважно з колагенових волокон. У бічному відлілі колагенові волокна сполучені між собою, а також з елауніновими та окситалановими волокнами, що розташовані близько судин. В апікальному відділі навколо судин розміщена пухка сполучна тканина.

Ключові слова: зуби, періодонтальна щілина, колагенові, окситаланові, елаунінові волокна.

\section{П. А. Гасюк, А. М. Король, А. В. Калашников \\ ГВУЗ «Тернопольский государственный медицинский университет имени И. Я. Горбачевского» \\ ВГУЗ Украины «Украинская медицинская стоматологическая академия», г. Полтава \\ Гистотопографические особенности периодонтальной щели зуба в эксперименте}

Резюме. Авторы проводили гистотопографические исследования периодонтальной щели зубов у собак и пришли к выводу, что маргинальный отдел связочного аппарата состоит преимущественно из коллагеновых волокон. В боковом отделе колагеновые волокна связаны между собою, а также с элауниновыми и окситалановыми волокнами, которые размещаются возле сосудов. В апикальном отделе толстая соединительная ткань размещается возле сосудов.

Ключевые слова: зубы, периодонтальная щель, коллагеновые, окситалановые, элауниновые волокна.

\section{P. A. Hasiuk, D. M. Korol, D. V. Kalashnikov \\ SHEI «Ternopil State Medical University by I. Ya. Horbachevsky» \\ HSEI of Ukraine «Ukrainian Medical Stomatological Academy», Poltava \\ Hystotopografic features of the periodontal ligament of the tooth in the experiment}

Summary. Authors conducted hystotopographic investigations periodontal slit of the dog's teeth and came to the conclusion that marginal part of connective apparatus is compososed mainly from collagenic fibers. In the lateral section of the collagenic fibers are connectod with each other as well as with elaunic and exitalanic fibers which are located near vessels. In the apical section the plump connective tissue is located near the vessels.

Key words: teeth, periodontal slit, collagenic, oxitalanic, elaunic fibers. 
Вступ. Як свідчать дані літератури [1-3], пародонт є досить добре васкуляризованою частиною зубощелепної системи. Основним джерелом кровопостачання періодонта $€$ альвеолярна артерія, від якої відходять гілки зубної артерії, що проникає в пульпу зуба, та міжзубна артерія, яка кровопостачає зубну альвеолу. Між зубною і міжзубною артеріями завдяки чисельним анастомозам утворюється супраперіостальна артерія, що живить безпосередньо періодонт.

Зважаючи на вищеописані анатомічні особливості кровопостачання періодонта, ми провели поглиблене його вивчення з урахуванням взаємного розташування судин відносно тканинних структур періодонта (зв'язковий апарат, цемент, кісткові балочки тощо), що і стало метою дослідження.

Матеріали і методи. Вивчення проводили на декальцинованих блоках щелеп собак, які містили у собі зуб, періодонт і прилеглу альвеолярну кістку.

Аекальциновані блоки перед заливанням у парафін поділяли на 3 частини: маргінальну, що включала коронку зуба, ясна та альвеолярний гребінь; середню частину, в якій локалізувалися корені зуба та альвеолярний відросток; нижню частину, яка містила в собі апікальну частину кореня зуба та щелепну кістку. Таким чином, вивчено 24 блоки верхньої і нижньої щелеп собак. Аля досліджень використовували безпородних собак масою $12-15$ кг.

Аекальциновані блоки підлягали звичайній парафіновій гістологічній проводці. Надалі виготовляли серійні гістотопографічні зрізи, у деяких випадках орієнтовані у вестибулолінгвальному, а в частині випадків - у мезіодистальному напрямках.

Отримані зрізи фрарбували звичайними гістологічними методами: гематоксиліном і еозином та пікрофуксином за методом Ван Гізон із дофарбуванням за Хартом.

Результати досліджень та їх обговорення. Проведені гістологічні дослідження маргінальної частини періодонта показують, що волокнисті структури в даному відділі мають різний хід. Так, на вертикальному зрізі, орієнтованому на вісь зуба в маргінальному відділі при фарбуванні за способом Ван Гізон, розрізняють три типи колагенових волокон, що утворюють зубоясенну, альвеолярно-ясенну і транссептальну зв'язки.
Зубоясенна зв'язка відходить від судин підслизового шару ясен і має косий напрямок пучків колагенових волокон. Альвеолярноясенна зв'язка, на відміну від попередньої, не має чіткого орієнтування пучків колагенових волокон. Це позв'язано з тим, що вони зрізані в косому напрямку.

Транссептальна зв'язка утворена подовжніми пучками колагенових волокон, що починаються від судин сітчастого шару ясен і закінчуються на гребені альвеолярного відростка.

Більш детальну будову маргінальної частини періодонта ми отримали на вертикальних відносно осі зуба зрізах, пофрарбованих пікрофуксином-фуксиліном (за Ван Гізон із дофрарбовуванням за Хартом) (рис. 1).

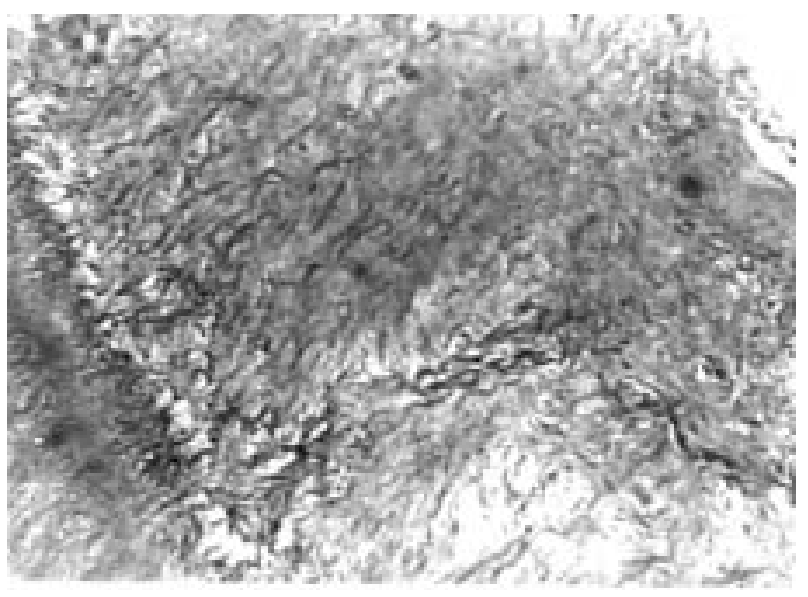

Рис. 1. Судинно-нервовий пучок, що проникає в маргінальний періодонт і йде з підслизового шару ясен. Забарвлення пікрофуксином за Ван

Гізон із дофарбуванням за Хартом. × 180.

Встановлено, що поряд із колагеновими маргінальний періодонт містить проеластичні та еластичні волокна.

Необхідно зазначити, що в зубоясенних волокнах навколо судин сосочкового шару ясен виявляються тонкі окситаланові проеластичні волокна. Альвеолярно-ясенна зв'язка містить більш товсті за діаметром елаунінові волокна. Завдяки наявності останніх відбувається утворення грубих пучків колагенових волокон зазначеної зв'язки.

Зрештою, у транссептальних зв'язках за ходом судин міжзубних артерій і вен визначають товсті еластичні волокна. Їх хід має вигляд параболи, що розташовується на гребені альвеолярного відростка.

ISSN 23 1-9624. Кпінічна стоматопогія. 2014. № 2 
Вивчення гістологічних препаратів зв'язкового апарату бічного відділу періодонтальної щілини зуба в собаки представлено на рисунку 2.

Періодонтальна щілина зубів у собак розташовується між цементом і кісткою альвеолярного гребеня. Цемент безпосередньо покриває дентин і складається з перпендикулярно розташованих до дентину цементобластів, між якими розташовуються тонкі волокнисті структури (цементиклі) та основна речовина. Необхідно зазначити, що іноді всю товщу цементу пронизують фуксинофільні колагенові волокна (шарпеєвські волокна), що досягають дентину.

Зв' язковий апарат бічного відділу періодонтальної щілини представлений циркулярними волокнистими структурами. Аані структури й утворюють косі волокна циркулярної зв'язки зуба. Вони в середній частині роздіяяються циркулярними судинами супраперіостальної артерії, що утворюється в основному з гілок міжзубної артерії.

Альвеолярна кістка, що прилягає до зв'язкового апарату, пронизується чисельними шарпеєвськими колагеновими волокнами, що перпендикулярно йдуть відносно окістя. Іноді вони проникають у просвіт гаверсових каналів. Більш детальне мікроскопічне вивчення ділянки бічного відділу періодонтальної щілини показує, що особливістю супраперіостальної артерії є майже повне закриття її просвіту, що звичайно буває характерно Аля «замикаючого» типу артеріо-венозних анастомозів.

Колагенові волокна, маючи сфінктери, у фізіологічних умовах регулюють рух крові. Безсумнівний інтерес становлять виявлені нами поблизу артерій тонкі й середні проела-

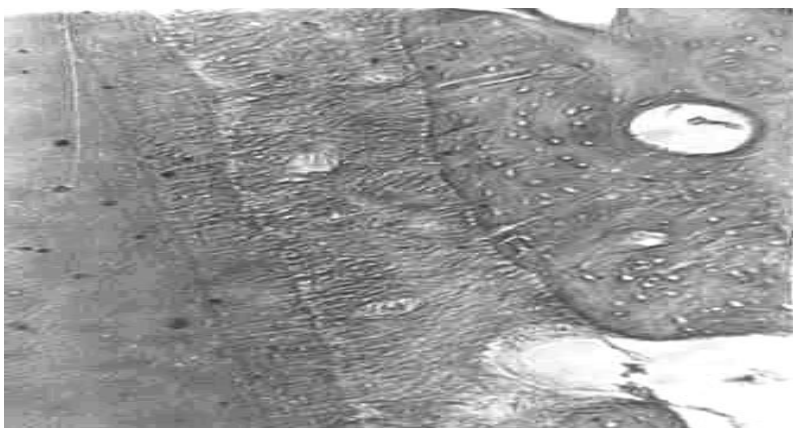

Рис. 2. Будова зв' язкового апарату бічного відділу періодонтальної щілини (циркулярна зв'язка). Забарвлення за Ван Гізон із дофарбуванням за Хартом. $\times 90$. стичні окситаланові фуксинофільні волокна. Останні, переплітаючись між собою, утворюють сплетення, що сприяє утриманню судин.

Колагенові волокна, на відміну від проеластичних, більш товсті й забарвлюються фуксином у червоний колір. Ці волокна місцями утворюють грубі пучки і пронизують з одного боку цемент, а з іншого - окістя альвеолярної кістки у вигляді шарпеєвських волокон.

Як показують результати гістотопографічних досліджень апікального відділу періодонтальної щілини, вони трохи відрізняються від бічного.

Від цементу кореня зуба до ділянок кісткової тканини альвеолярного відростка відходять численні колагенові волокна. Місцями близько цементу вони утворюють грубі пучки, які у вигляді шарпеєвських волокон пронизують майже всю товщу цементу. Подібні грубоволокнисті пучки визначаються і поблизу кісткової лунки. Вони у вигляді шарпеєвських волокон пронизують гаверсові канали.

Необхідно зазначити, що центральна частина пучків колагенових волокон переривається судинно-нервовим сплетенням, до складу якого входить артерія з двоеластичним контуром еластичних мембран, а також венула, контури якої чітко не визначаються.

Проведене більш детальне мікроскопічне вивчення будови апікального відділу періодонтальної щілини представлено на рисунку 3.

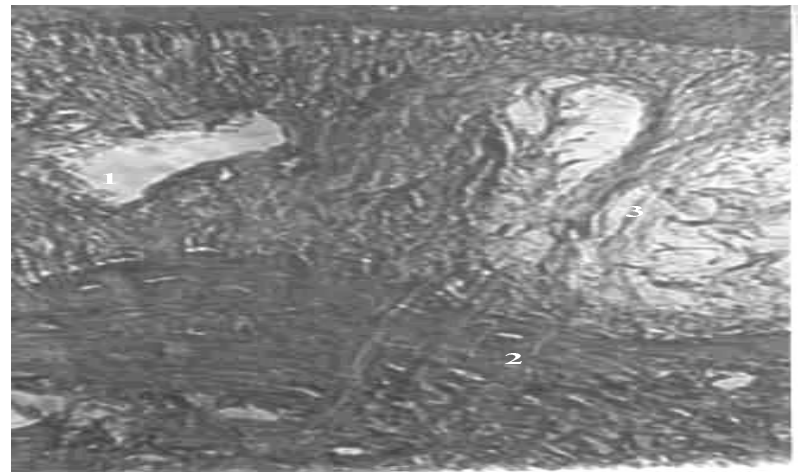

Рис. 3. Розташування колагенових волокон апікального відділу періодонтальної щілини: 1 - венозні судини періодонта з рівномірним розташуванням колагенових волокон (світлих),

2 - колагенові шарпеєвські волокна, що пронизують кісткові балочки гаверсових каналів альвеолярної кістки,

3 - периваскулярне розташування фрібробластів і фіброцитів. Забарвлення пікрофуксином-фруксиліном. × 360 . 
Встановлено, що шарпеєвські волокна пронизують вставні диски гаверсових каналів та іноді досягають просвіту гаверсового отвору. Навколо судин колагенові волокна стоншуються, фрормуючи навколо вен пухку сполучну тканину. Шарпеєвські волокна, що пронизують товщу цементу, трохи тонші.

Необхідно зазначити, що на відміну віА бічного відлілу, в апікальному відділі періодонтальної щілини окситаланові та елаунінові

\section{Список літератури}

1. Быков В. А. Гистология и эмбриология органов полости рта человека / В. А. Быков. - СПб., 1996. - 246 с. 2. Серов В. В. Соединительная ткань / В. В. Серов, А. Б. Шехтер. - М. : Медицина, 1981. - 312 с. волокна не зустрічаються. Це, на наш погляд, зумовлено функціональними особливостями періодонта, що необхідно для амортизації зуба.

Висновки. Результати проведених досліАжень маргінального відділу періодонта зубів собак свідчать про наявність трьох типів зв'язок, кожна з яких відходить від визначеної суАини і прикріплюється до визначеного анатомічного утвору зуба, а також має різну будову.

3. Фалин $\curlywedge$. И. Гистология и эмбриология полости рта и зубов / А. И. Фалин. - М. : Медицина, 1963. - 220 с.

Отримано 10.04.14 